\title{
New autosomal recessive faciodigitogenital syndrome
}

\author{
AHMAD S TEEBI*, KAMAL K NAGUIB*, SADIKA A AL-AWADI*, AND \\ QASEM A AL-SALEH†
}

From *Kuwait Medical Genetics Centre, Maternity Hospital; and tDermatology Department, Al-Sabah Hospital, Kuwait.

SUMmaRY Most pedigrees of Aarskog's faciodigitogenital syndrome have suggested X linked inheritance. However, sex influenced autosomal dominant inheritance is also a possibility in some families. We describe an Arab family of normal consanguineous parents with five children (three males and two females) with some features of Aarskog syndrome in addition to some unusual hair changes. The possibility that this family represents a distinct previously unrecognised faciodigitogenital syndrome with short stature and hair abnormalities is suggested and discussec.

In 1970 Aarskog $^{1}$ described a syndrome of short stature with facial and genital anomalies in seven males from two generations in a family. Earlier probable cases were reported from the USA in 1966 by Welch and Temtamy ${ }^{2}$ and in 1967 by Hanley et $a{ }^{3}{ }^{3}$ Since then, many reports over two decades have shown that males show full expression and that in females expression, if present, is limited to minor signs only; therefore $\mathrm{X}$ linked recessive, $\mathrm{X}$ linked semi-dominant, or sex influenced autosomal dominant inheritance have been suggested. Full

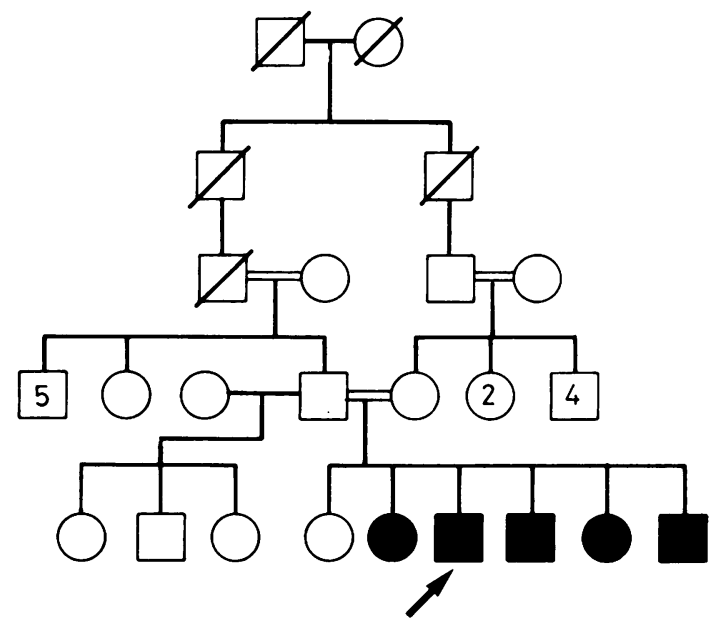

FIG 1 Family pedigree.

Received for publication 16 February 1987.

Revised version accepted for publication 9 July 1987 male and female expression has been noted recently by Bawle $e a^{4}$ in a mother and her son who have the same balanced $\mathrm{X}$; autosome translocation. Here we report on a family with five affected sibs, males and females, who have a distinct disorder with several features resembling Aarskog's faciodigitogenital syndrome.

\section{Case reports}

CASE 1

The proband, a six year old male, was examined in

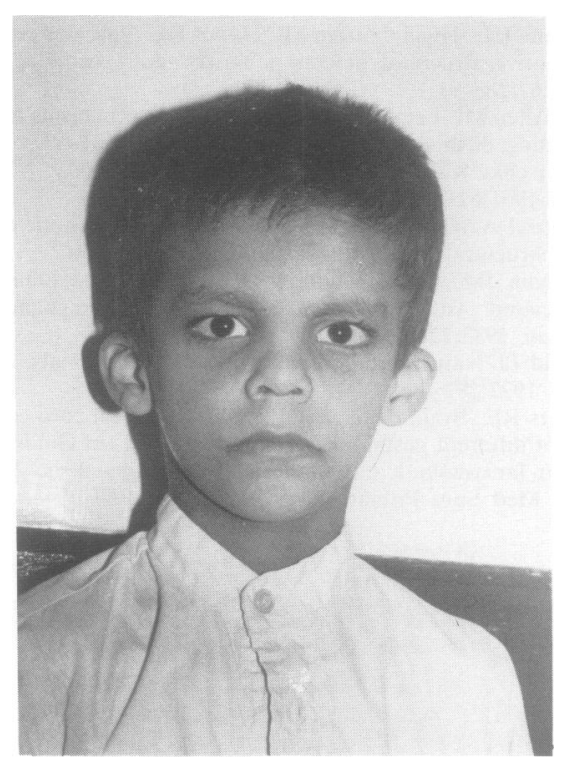

FIG 2a Front view of case 1. 


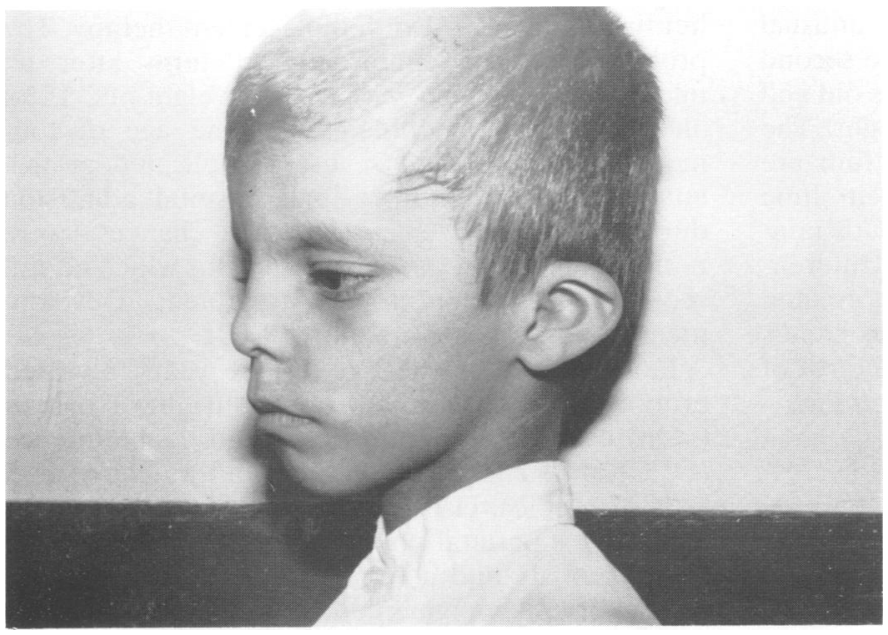

FIG $2 \mathrm{~b}$ Side view of case 1 .

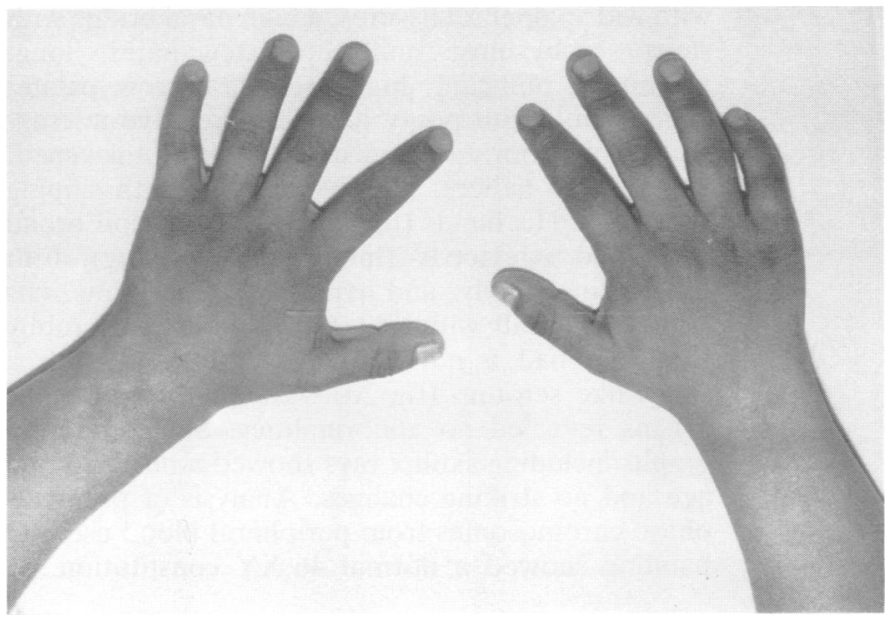

FIG 2c Hands of case 1 .

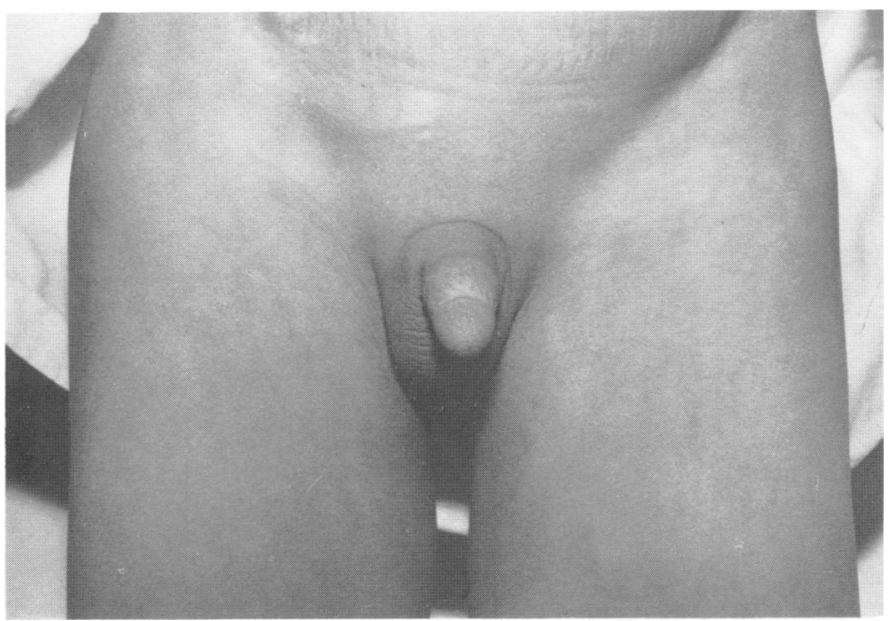

FIG 2d External genitalia of case 1. 
October 1985 because of short stature, unusual facies, and lax hand joints. His parents are second cousin Kuwaiti Bedouins. Both are 38 years old and phenotypically normal with an average height. The proband has five brothers and sisters and four are similarly affected; one of them was born in June 1986. His father is married to a second nonconsanguineous wife and has three normal children. Family study showed no other closely related members with similar features (fig 1). The proband's mother had a total thyroidectomy after the birth of

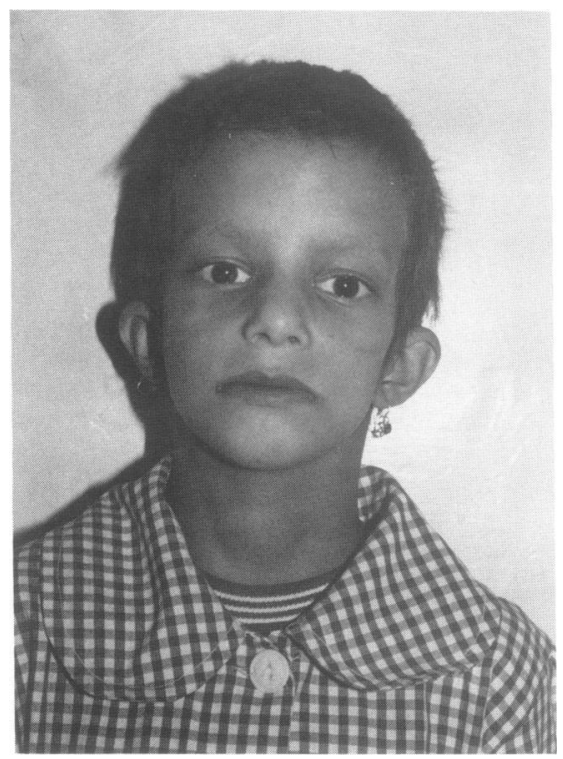

FIG 3a Front view of case 2. her first child in 1974 with replacement therapy. The proband was born normally at term after an? uneventful pregnancy with a birth weight of $2 \cdot 15 \mathrm{~kg}$ 등 and no neonatal problems. At the age of four $\frac{\bar{c}}{\frac{0}{6}}$ months he developed severe complicated gastro- $\bar{\sigma}$ enteritis and required a long hospital admissiono during which eczema-like skin changes werew noticed, mainly on the extremities, for which he still $\overrightarrow{0}$ receives intermittent topical treatment. Developmental milestones were normal.

Examination at the age of six years revealed $\stackrel{\text { }}{\circ}$ proportionate short stature with a height of $104 \mathrm{~cm}$ (<3rd centile), occipitofrontal head circumferencein (OFC) of $47 \mathrm{~cm}$ (<3rd centile), and weight of $15.5 \mathrm{c}$ $\mathrm{kg}$ (3rd centile). His craniofacial features (fig $2 \mathrm{a}, \mathrm{b}$ ) included biparietal bossing of the skull witho brachycephaly and a triangular face. His hair was응 coarse, dry, hypopigmented, and slightly sparse with_a widow's peak. He had apparent hypertelorismc with wide palpebral fissures, a high nasal bridge with short stubby nose and anteverted nares, long, $\vec{c}$ prominent philtrum, high arched, narrow palate,,$\infty$ wide mouth with pouty lower lip, relative microg- $-\infty$ nathia, posteriorly rotated small ears with thickened, downturned helices, and a long neck with sloping shoulders. His hands (fig 2c) were small and broado with mild syndactyly (interdigital webbing), fifth finger clinodactyly, and hyperextensible joints. His $\stackrel{\complement}{\complement}$ feet were small with metatarsus varus and stubby $\overrightarrow{\vec{A}}$ toes. He had a normal penis and testes with a응 shawl-like scrotum (fig 2d). Examination of other organs revealed no abnormalities. Skeletal radiographs including skull $x$ rays showed a normal bone age and no striking changes. Analysis of prometaphase chromosomes from peripheral blood using $\mathrm{G}^{\circ}$ banding showed a normal $46, \mathrm{XY}$ constitution.

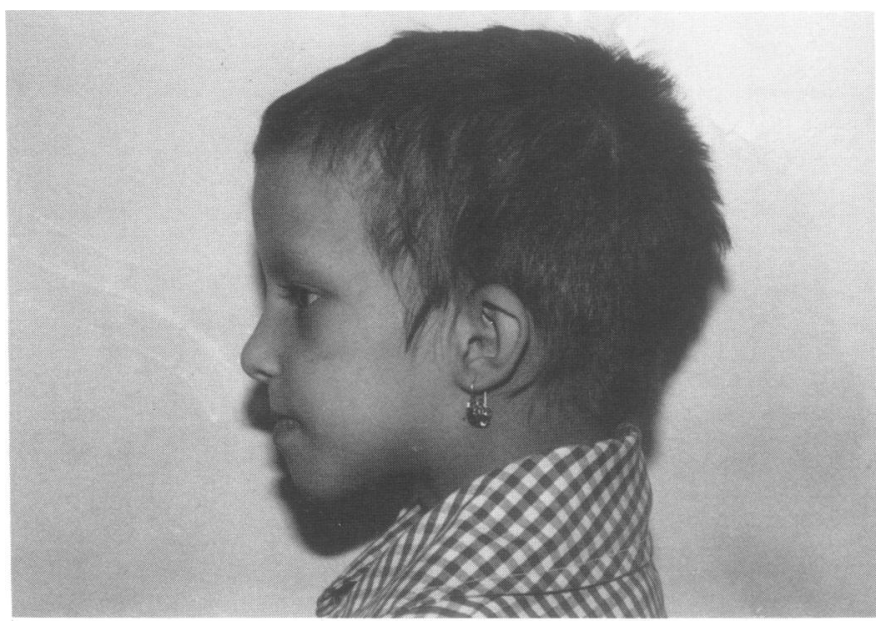

FIG 3b Side view of case 2 . 


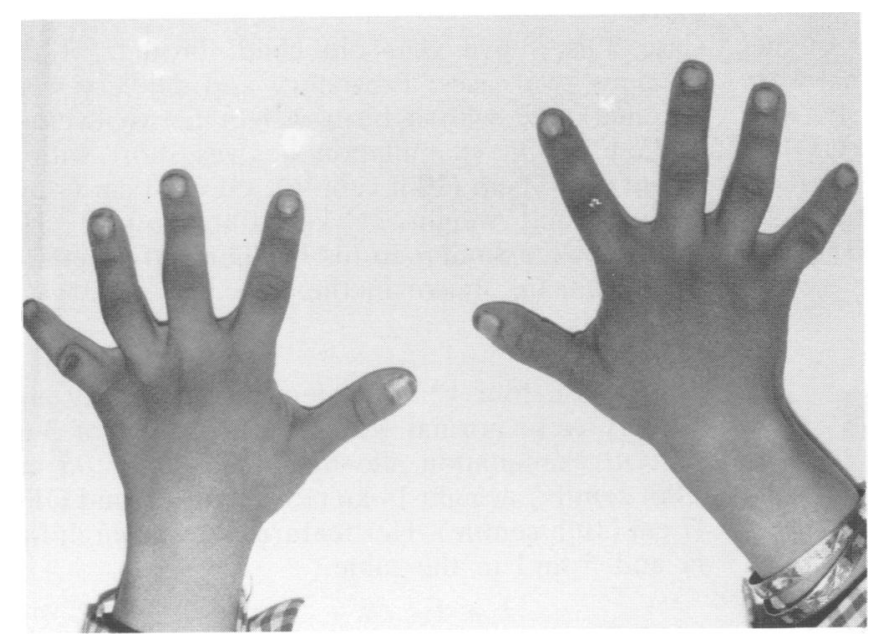

FIG 3c Hands of case 2.

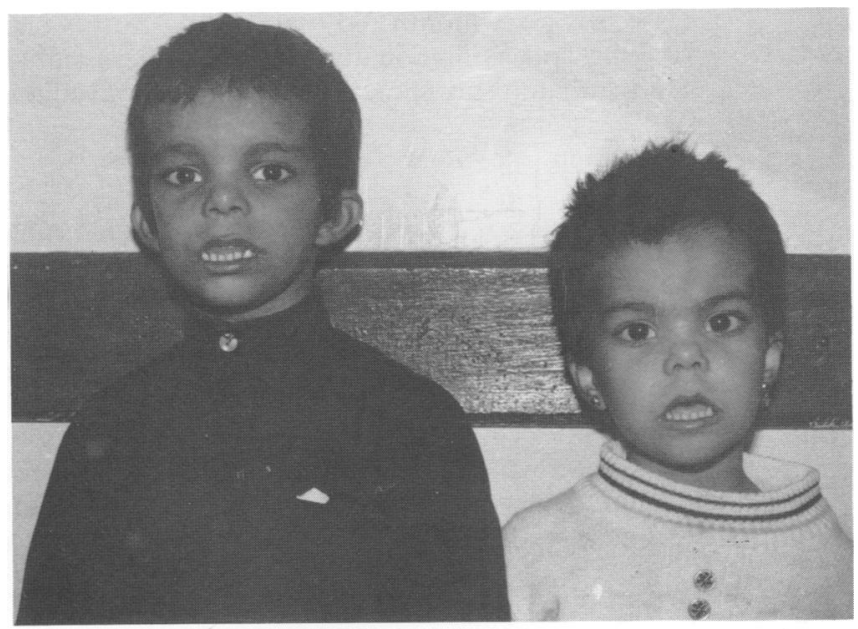

FIG $4 \mathrm{a}$ Case 3 and case 4.

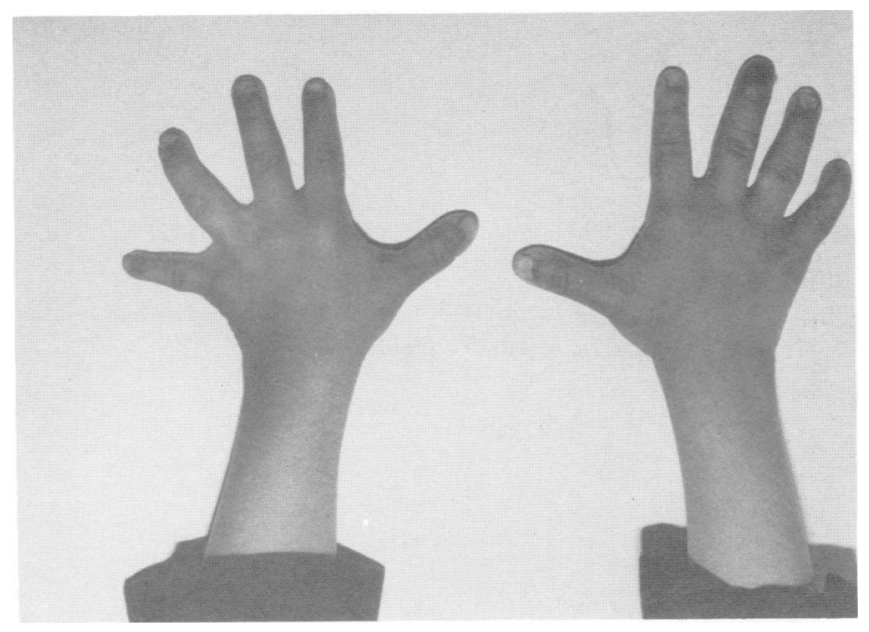

FIG $4 \mathrm{~b}$ Hands of case 3. 
CASE 2

Case 2 is a seven year old child, the sister of the proband. Pregnancy and delivery were normal with a birth weight of $3.5 \mathrm{~kg}$. On examination she was short with a height of $100 \mathrm{~cm}(<3$ rd centile $)$, OFC $48 \mathrm{~cm}$ ( $<3 \mathrm{rd}$ centile), and weight $18.5 \mathrm{~kg}$ (3rd centile). Her features (fig 3a-c) were strikingly similar to the proband and are summarised in the table.

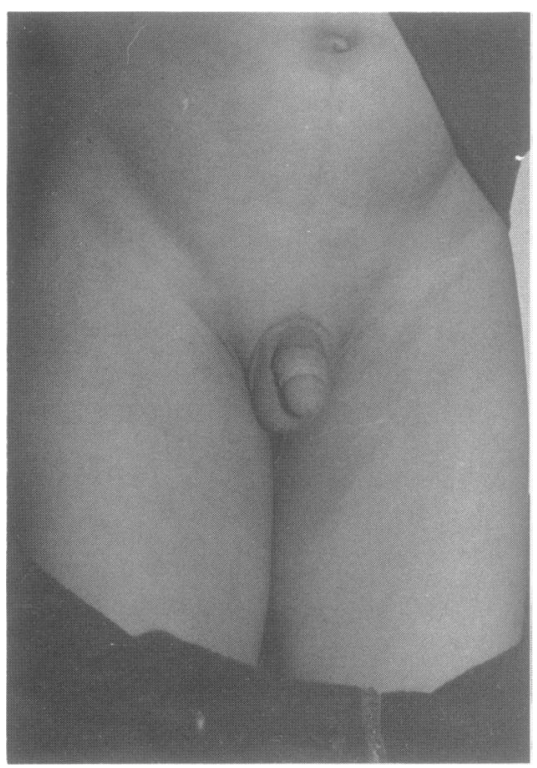

FIG 4c External genitalia of case 3.

\section{CASE 3}

Case 3 is a five year old child, brother of the $\stackrel{\vec{\rho}}{+}$ previous two cases. Pregnancy and delivery were? unremarkable with a birth weight above average $\frac{\bar{\sigma}}{\bar{\omega}}$ $(3.75 \mathrm{~kg})$. On examination he was short with a? height of $102 \mathrm{~cm}$ (10th centile), OFC $47 \mathrm{~cm}\left(<3 \mathrm{rd}_{\complement}\right.$ centile), and weight $16 \mathrm{~kg}$ (10th centile). His尺 features were similar to his brother and sister (fig $\overrightarrow{0}$ $4 a-c)$ and are shown in the table.

\section{CASE 4}

Case 4 is a four year old female. Pregnancy and $\overline{3}$ delivery were normal with a birth weight of $3.65^{\circ}$ $\mathrm{kg}$. On examination she had a height of $95 \mathrm{~cm}$ (T) (10th centile), weight $14 \mathrm{~kg}$ (10th centile), and OFC $47 \mathrm{~cm}$ (10th centile). Her features are shown in figs 8 4a and 5 and in the table.

\section{CASE 5}

Case 5 is a six month old male with a birth weight of $3 \mathrm{~kg}$ and similar features to the others (table). Unfortunately no clinical photograph is available.

\section{Discussion}

On the basis of a family with seven affected males and no male to male transmission of the trait over two generations, Aarskog ${ }^{1}$ suggested $X$ linked $\stackrel{\square}{\complement}$ recessive inheritance for Aarskog's faciodigitogeni- $\Rightarrow$ tal syndrome. Subsequently, other authors sup-응 ported this view. ${ }^{5-17}$ Further reports of male $-{ }_{-}$ patients, ${ }^{18-24}$ more than 110 so far, show complete expression which includes, in addition to the 'shaw scrotum', short stature, a round face, prominent forehead with widow's peak, hypertelorism, broado-

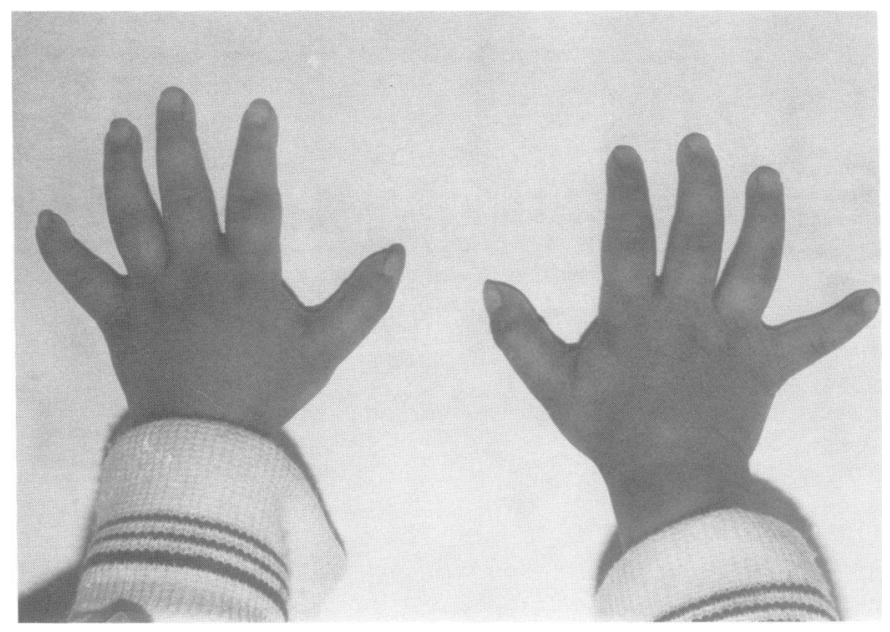

FIG 5 Hands of case 4. 
TABLE 1 Features of the five sibs.

\begin{tabular}{|c|c|c|c|c|c|}
\hline Features & $\begin{array}{l}\text { Case I } \\
\text { (proband) }\end{array}$ & Case 2 & Case 3 & Case 4 & Case 5 \\
\hline Age & $6 y$ & $7 y$ & $5 y$ & $4 y$ & $6 \mathrm{mth}$ \\
\hline Sex & $M$ & $\mathrm{~F}$ & $\mathrm{M}$ & $\mathrm{F}$ & $\mathbf{M}$ \\
\hline Short stature (at or below 10th centile) & + & + & + & + & - \\
\hline Hair changes (coarse, dry, and hypopigmented) & + & + & + & + & - \\
\hline Widow's peak hair anomaly & + & + & - & + & + \\
\hline Skull bossing & + & - & - & + & + \\
\hline Brachycephaly & + & - & - & - & + \\
\hline Triangular or elongated face & + & + & + & + & - \\
\hline Apparent hypertelorism & + & + & + & + & + \\
\hline Wide palpebral fissures & + & + & + & - & + \\
\hline Upward slanting eyes & - & - & - & + & + \\
\hline High nasal bridge & + & + & - & - & - \\
\hline Short stubby nose & + & + & + & + & + \\
\hline Anteverted nares & + & + & + & + & + \\
\hline Long. deep philtrum & + & + & + & + & + \\
\hline Wide mouth & + & + & + & + & + \\
\hline Pouty lower lip & + & + & + & + & + \\
\hline High and narrow palate & + & + & + & + & + \\
\hline Dental malocclusion & -. & + & + & + & - \\
\hline Relative micrognathia & + & - & - & - & - \\
\hline Ear anomalies & + & + & + & - & + \\
\hline Long neck with sloping shoulders & + & + & + & + & + \\
\hline Pectus excavatum & - & - & - & + & + \\
\hline Clinodactly of 5th finger & + & + & + & + & - \\
\hline Small and broad hands & + & + & + & + & + \\
\hline Interdigital webbing & + & + & + & + & + \\
\hline Hyperextensible hand joints & + & + & + & + & - \\
\hline Hyperelastic skin & - & + & - & - & - \\
\hline Metatarsus varus & + & - & - & + & - \\
\hline Bulbous toes & + & + & + & + & + \\
\hline Shawl scrotum & + & - & + & - & + \\
\hline IQ or DQ & Normal & Normal & Normal & Normal & Normal \\
\hline Bone age & Normal & Normal & Normal & Normal & Normal \\
\hline \multirow[t]{2}{*}{ Karyotype } & Normal & Normal & Normal & - & - \\
\hline & $46 . X Y$ & $46 . \mathrm{XX}$ & $46 . X Y$ & & \\
\hline
\end{tabular}

nasal bridge, short, stubby nose with hypoplastic maxilla, and small hands with interdigital webbing. In females expression, if present, is partial and limited to minor signs only. ${ }^{8} 2^{25-27}$ Therefore, $\mathrm{X}$ linked semidominan ${ }^{25}$ or sex influenced autosomal dominant inheritance has been suggested. ${ }^{18} 212426$ However, Berman et $a l^{8}$ suggested that autosomal dominant inheritance is unlikely based on statistical analysis of four reported affected males who produced seven normal sons. However, a few examples of male to male transmission of Aarskog syndrome have been documented. ${ }^{21} 26$ In a large family reported recently there was one male with short stature, ptosis, antimongoloid eye slant, and thickened ear lobes who transmitted ptosis and antimongoloid slant to one son and antimongoloid slant and thickened ear lobes to another son. ${ }^{24}$ Recently, complete expression of the syndrome in a mother and her son who have the same balanced $\mathrm{X}$;autosome translocation has been reported. ${ }^{4}$ The authors concluded that Aarskog syndrome is an $\mathrm{X}$ linked disorder and that $\mathrm{Xq} 13$ is the likely site of its locus.

The males and females in this family have small stature with all body proportions at or below the
10 th centile. They also show several features similar to those of Aarskog syndrome. They include normal intelligence, hand and foot anomalies, and some characteristic facial features with apparent hypertelorism, short, stubby nose, anteverted nostrils, and ear anomalies, but without antimongoloid slanting of the eyes or ptosis. The males had penoscrotal skin folds, commonly described as shawl scrotum, which is considered to be one of the diagnostic criteria of Aarskog syndrome. In addition, males and females have hair abnormalities not previously described in Aarskog syndrome.

Affected subjects in this family appear to have a new faciodigitogenital syndrome readily distinguishable from the well characterised Aarskog syndrome. In the absence of any chromosomal abnormality with five affected male and female sibs and parental consanguinity, autosomal recessive inheritance is highly likely.

We are grateful to Drs J G Hall and B D Hall for seeing the clinical photographs of these patients and encouraging us to write this report. We thank Dr D S Krishna Murthy for performing chromosomal analysis and Mrs R Ratos for typing the manuscript. 


\section{References}

1 Aarskog D. A familial syndrome of short stature associated with facial dysplasia and genital anomalies. $J$ Pediatr 1970;77: 856-61.

${ }^{2}$ Welch JP, Temtamy S. Hereditary contractures of the fingers (camptodactly). J Med Genet 1966;3:104-13.

${ }^{3}$ Hanley WB, McKusick VA, Barranco FT. Osteochondritis dissecans with associated malformations in two brothers. $J$ Bone Joint Surg (Am) 1967;49:925-37.

${ }^{4}$ Bawle E, Tyrkus M, Lipman S, Bozimowski D. Aarskog syndrome: full male and female expression associated with $\mathrm{X}$ autosome translocation. Am J Med Genet 1984;17:595-602.

5 Scott CI. Unusual facies, joint hypermobility, genital anomaly and short stature: a new dysmorphic syndrome. In: Bergsma D, ed. The endocrine systems. Part X. New York: March of Dimes, 1971:240-6.

6 Kunze J, Spranger J. Aarskog syndrome. Klin Paediatr 1973; 185:490-4.

${ }^{7}$ Berman P, Desjardins C, Fraser FC. Inheritance of the Aarskog syndromes: In: Bergsma D, ed. Malformation syndromes. Miami: National Foundation-March of Dimes, 1974:151-9.

${ }^{8}$ Berman P, Desjardins C, Fraser FC. The inheritance of the Aarskog facial-digital-genital syndrome. J Pediatr 1975;86: 885-91.

${ }^{9}$ Kirkham TH, Milot J, Berman P. Ophthalmic manifestations of Aarskog (facial-digital-genital) syndrome. Am J Ophthalmol 1975;79:441-5.

10 Duncan P, Klein RM, Wilmont PL, Shapiro LR. Additional features of the Aarskog syndrome. J Pediatr 1977;86:885-91.

$"$ Escobar Y, Weaver DD. Aarskog syndrome. JAMA 1978;240: 2638-41.

12 Fryns JP, Macken J, Vinken L, Igodt-Ameye L, van den Bergh H. The Aarskog syndrome. Hum Genet 1978;42:129-35.

13 Ricotti GC, Giovannucci-Uzielli ML, Pepi M, Prosperi P, Torricelli F. La sindrome di Aarskog. Acta Med Auxol 1978;10:135-50.

14 Andrassy RJ, Murthy S, Woolley MM. Aarskog syndrome: significance for the surgeon. J Pediatr Surg 1979;15:462-4.
15 Berry C, Cree J, Mann T. Aarskog's syndrome. Arch Dis Child 1980;55:706-10.

${ }^{16}$ Hassinger DD, Mulvihill JJ, Chandler JB. Aarskog's syndrome $\overrightarrow{0}$ with Hirschsprung's disease, midgut malrotation and dental anomalies. J Med Genet 1980;17:235-8.

17 Kodama M, Fujimoto S, Namikawa T, Matesuda I. Aarskog $\frac{\bar{\sigma}}{\partial}$ syndrome with isolated growth hormone deficiency. Eur $J \mathbb{D}$ Pediatr 1981;135:273-6.

18 Saggese G, Bertelloni S, Baroncelli GI, Calisti L. Aarskog's कొ syndrome. Description of a case and endocrinological study. $\vec{O}$ Pediatr Med Chir 1983;5:613-8.

${ }^{19}$ de Saxe M, Kromberg JG, Jenkins T. The Aarskog (faciodigital-genital) syndrome in South Africa. A report of three families. S Afr Med J 1984;65:299-303.

20) van den Bergh P, Fryns JP, Wilms G, Piot R, Dralands G, van den Bergh R. Anomalous cerebral venous drainage in Aarskog syndrome. Clin Genet 1984;25:288-94.

${ }^{21}$ Grier RE, Farrington FH, Kendig R, Mamunes P. Autosomal $\sigma$ dominant inheritance of the Aarskog syndrome. Am J Med it Genet 1983;15:39-46.

22 Hurst DL. Metatarsus adductus in two brothers with Aarskog 0 syndrome. J Med Genet 1983;20:477.

23 Shinkawa T, Yamauchi Y, Osada Y, Ishisawa N. Aarskog syndrome. Urology 1983;22:624-6.

24 van de Vooren MJ, Niermeijer MF, Hoogebdon AJ. The Aarskog syndrome in a large family, suggestive of autosomal dominant inheritance. Clin Genet 1983;24:439-45.

${ }^{25}$ Furukawa CT, Hall BD, Smith DW. The Aarskog syndrome. $J \infty$ Pediatr 1972;81:1117-22.

26 Sugarman GI, Rimoin DL, Lachman RS. The facial digitalgenital (Aarskog) syndrome. Am J Dis Child 1973;126:248-52. \}

27 Oberiter V, Lovrencic MK, Schmutzer L, Kraus O. The Aarskog syndrome. Acta Paediatr Scand 1980;69:567-70.

Correspondence and requests for reprints to $\frac{\varnothing}{2}$ Dr Ahmad S Teebi, Kuwait Medical Genetics Centre, Maternity Hospital, PO Box 36660, 24757윽 Raas, Kuwait. 